\title{
Determining the spacing of acoustic call count stations for monitoring a widespread forest owl
}

\author{
Moira A. Pryde* and Terry C. Greene \\ Department of Conservation, Science and Policy, 70 Moorhouse Avenue, Christchurch 8011, New Zealand \\ *Author for correspondence (Email: mpryde@doc.govt.nz) \\ Published online: 15 September 2015
}

\begin{abstract}
Nocturnal species are challenging to monitor, but with advances in bioacoustic technology, acoustic monitoring is becoming a more affordable, efficient technique for monitoring cryptic species. We tested the suitability of acoustic monitoring as a potential national monitoring method for morepork/rūrū (Ninox novaeseelandiae), in beech forest within the Eglinton Valley, Fiordland, during spring 2009-2010. We used radio telemetry and an acoustic call study to address two questions to help managers make evidence-based decisions on the spacing of acoustic call count stations: (1) What are the sex-specific and seasonal home-range sizes of rūrū? (2) How does acoustic detection decrease with increasing distance? Home ranges were the largest recorded to date for rūrū in New Zealand (mean $100 \% \mathrm{MCP}=307$ ha, mean $75 \%$ kernel $=43.5$ ha) with an average range spread of $270 \mathrm{~m}(75 \% \mathrm{kernel})$. Significant attenuation of recorded calls occurred after $150 \mathrm{~m}$ in southern beech (Nothofagaceae) forest and no calls could be detected by the recorders beyond 250 $\mathrm{m}$. Acoustic monitoring is a promising technique to monitor rūrū nationally, but the spacing of stations needs to vary depending on home-range, habitat and the microphones used in the acoustic detectors.
\end{abstract}

Keywords: acoustic monitoring; acoustic recording devices; home range; morepork, Ninox novaeseelandiae; rūrū

\section{Introduction}

Reliable, robust monitoring methods are required to monitor species distribution and density, to determine long-term population trends and to assess ecosystem health (Macleod et al. 2012). Although common and widespread species are important for ecosystem function and structure, quantitative information on the population status of many common species is lacking. Detecting population trends using efficient and reliable monitoring systems will contribute to conservation management decisions that help to maintain and restore biodiversity (Gaston \& Fuller 2007; Elliott et al. 2010; Macleod et al. 2012).

The Biodiversity Monitoring and Reporting System developed by the Department of Conservation (DOC) and Landcare Research (Lee et al. 2005) aims to provide a rigorous approach to quantifying biodiversity so that the population status and trend of species can be more accurately reported (Allen et al. 2009). The system uses a range of biodiversity indicators for reporting on the state of the environment (Hoare et al. 2010). Before sampling methods are introduced to the reporting framework, they are assessed for their suitability and, if possible, calibrated against actual density measures and standardised. Nationally standardised methodologies permit data to be collated from a range of sites and allow inferences to be drawn across a wide range of habitats. In the Eglinton Valley, Fiordland, for example, the status of New Zealand robin populations (Petroica australis) was assessed over a 5-year period using territory mapping and calibrated against a range of potential population estimators (Greene \& Pryde 2012).

The morepork or rūrū (Ninox novaeseelandiae) is a common and widespread New Zealand forest owl, and potentially suitable as a biodiversity indicator (Sergio et al. 2006). Rūrū are hole-nesting forest birds and therefore vulnerable to predation by introduced mammals (O'Donnell 1996). As a top predator, rūrū may be vulnerable to toxins used to control introduced mammals (Stephenson et al. 1999; Fraser \& Hauber 2008). Globally, owls have been shown to be a robust biodiversity indicator of ecosystem health and integrity (Blackburn et al. 2001; Anthony et al. 2006), and a range of monitoring methods have been developed, including using playback calls (Anthony et al. 2006), mouse lures (Imboden 1975), mark-re-sight (Blackburn et al. 2001), and acoustic monitoring (Gravia et al. 2008).

In New Zealand, little systematic rūrū monitoring has been undertaken, as direct counts are generally impractical and expensive. Indices of relative abundance derived from call count stations are more practical and cost-effective for widespread monitoring. Monitoring any species using call counts needs to be at an appropriate scale and must consider the biology of the species as well as the types of habitats involved.

Call-count stations need to be placed at suitable intervals to allow inference about populations to be made at an appropriate scale. Home range estimates can be used to inform the distance between count stations that maximises detection probability and minimises the potential of double counting territories (Ramsey et al. 2015). As home range and acoustic attenuation is likely to differ between habitats, the appropriate spacing of call count stations needs to be considered at each site. We addressed two questions to help managers make evidence-based decisions on the spacing of acoustic call count stations for monitoring relative population size of rūrū over time: (1) What are the sex-specific and seasonal home-range sizes of rūrū? (2) How does acoustic detection decrease with increasing distance?

\section{Methods}

\section{Study areas}

The Eglinton Valley, Fiordland, South Island, New Zealand $\left(44^{\circ} 58^{\prime} \mathrm{S}, 168^{\circ} 01^{\prime} \mathrm{E}\right)$ (Fig. 1), is c. $250-500 \mathrm{~m}$ above sea 


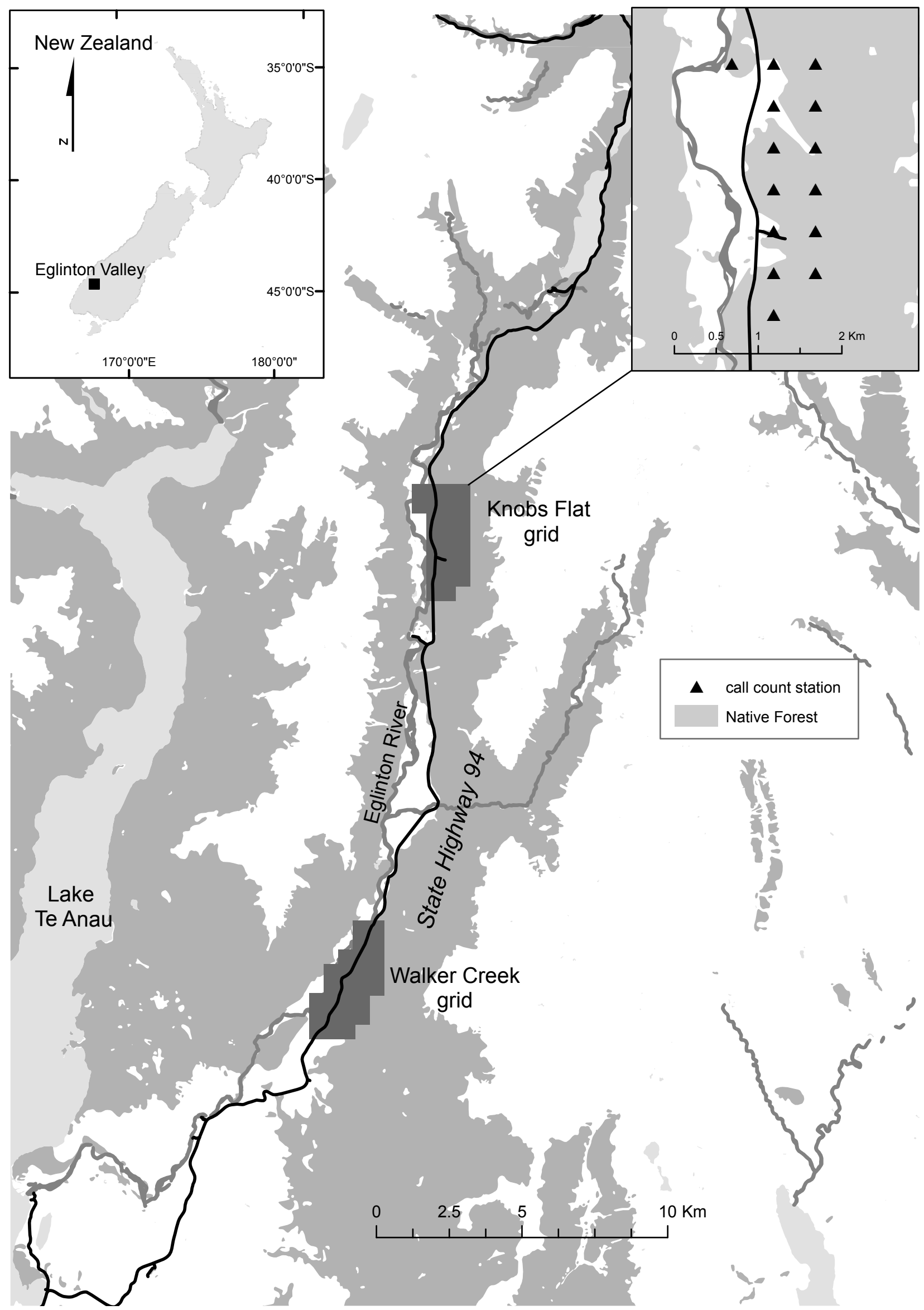

Figure 1. Location of the study sites (Knobs Flat and Walker Creek) in the Eglinton Valley, Fiordland, and the placement design of the acoustic call stations (shown by black triangles) for rūrū (Ninox novaeseelandiae) at Knobs Flat. 
level, glacial in origin and is steep-sided with a flat valley floor $0.5-1.5 \mathrm{~km}$ wide. Annual rainfall ranges from c. 1200 $\mathrm{mm}$ near the valley mouth to $>5000 \mathrm{~mm}$ at its headwaters. Partly modified grassland covers much of the valley floor. Terraces, outwash fans, and steep valley walls are covered with temperate beech (Nothofagaceae spp.) forest to the treeline at 1000-1200 $\mathrm{m}$ above sea level. Near the valley floor, the forest is dominated by red beech (Fuscospora fusca) and silver beech (Lophozonia menziesii), with mountain beech (Fuscospora cliffortioides) becoming more common with increasing altitude. The understorey is generally open, with few plants other than scattered broadleaf(Griselinia littoralis), small-leaved coprosmas (Coprosma spp.), and a ground cover of mosses (O’Donnell 2000).

Between September 2009 and October 2010 rūrū were captured and monitored at two sites within the Eglinton Valley: Knobs Flat and Walker Creek (Fig. 1). The Knobs Flat site, in the middle of the valley, is centred on a gently sloping alluvial fan with silver beech and a very open understorey that dominates the periphery. With increasing altitude and distance from the margins, the forest becomes taller and is dominated by red beech trees with a much denser understorey. The Walker Creek site is further (c. $14 \mathrm{~km}$ ) down the valley, and is consequently drier. Although the forest composition is similar to the Knobs Flat site, the forest at Walker Creek is generally taller. The topography is also more rugged, with a series of steep-sided alluvial terraces bisected by a number of gullies formed by small streams (Greene \& Pryde 2012).

\section{Study Design and Techniques}

\section{Radio-tagging rūrū}

Rūrū were captured for monitoring using mist nets erected in forested areas, and birds were lured to the nets using recorded local calls (Dilks et al. 1995). Each bird was fitted with an individual metal leg band and a small two-stage VHF mortality transmitter (Model RI-2C, Holohil Systems, Carp, Ont., Canada) using a standard backpack harness system with a weak link (Karl \& Clout 1987). Transmitters weighed $6.8 \mathrm{~g}$ and had a maximum operational life of 18 months. The transmitter harness system was the same as that used by Stephenson et al. (1998) and met DOC guidelines recommended for New Zealand forest birds (Gummer 2012).

\section{Tracking of rūru}

Tagged birds were tracked during the day to roosting trees. It was not feasible to radio-track and follow birds in the dark due to the terrain, forest density and the potential for disturbance. Nocturnal locations were estimated using triangulation of radio-tagged birds. This was conducted by a minimum of three people positioned at stationary points who were able to obtain fixes on birds using a handheld receiver (TR4, Telonics) and a Yagi aerial. Radio contact between observers allowed bearings to be synchronised and handheld compasses were used to measure bearings. Signal strength was used to estimate a rough distance to each bird. Consecutive attempts to locate birds were separated by a minimum interval of 10 minutes. This interval was thought sufficiently long to ensure independence of observations as rūrū are quite capable of traversing the length of their home range several times within this period. Tracking was carried out over several nights in August, September, October, November, January, March, and May (2009-2010). Nocturnal location data were collected over a total of 128 nights for about 3 hours each night between sunset and sunrise.

\section{Sampling design}

Each rūrū was considered as the sampling unit, with individual locations treated as subsamples to reduce pseudo-replication in the study design (Garton et al. 2001). We attempted to obtain 30-50 location estimates for each tagged bird over the sampling period to provide reliable home range sizes (Harris et al.1990; Seaman et al. 1999; Garton et al. 2001). Initially, the data were divided into the breeding season (October until March) and the non-breeding season (April until September) as it was likely that ranges would differ depending on the season and food availability. These data were aggregated for the final analysis as there was little breeding in 2009-10. Day and night locations were also treated separately in the first analysis as it was expected that the daytime roost range would be smaller than the night-time foraging range. Night and day ranges were then combined for the final analysis of total home range size as the daytime roost areas were all within the calculated home range.

Fourteen call count stations were set up on a grid at 500$m$ intervals within the forest at Knobs Flat (Fig. 1). Rūrū can be monitored either by a person standing at the station or, more conveniently for a nocturnal species, by an automated acoustic recording device (Buxton \& Jones 2012). To test for the independence of call count stations and the attenuation of calls within the forest, we played a standard rūrū call next to the recorder. We estimated the volume by recording individuals at close range and measuring the sound strength. We tested whether the call was heard using an acoustic recording device at $50-\mathrm{m}$ intervals within the forest. In this project we used acoustic recording devices developed by the Electronics Department, DOC (DOC, unpublished data). We played calls at eight locations and had acoustic recorders at 50-m intervals. Sixty-four calls were individually played.

\section{Data analysis}

To estimate point locations for rūrū, three or more bearings were plotted for each observation and the centre of the resultant polygon calculated using a custom-built GIS system(G. Elliott, DOC, pers. comm.). Location data derived from triangulations were only accepted following careful assessment of signal quality, landscape features and the potential for back signals, and size of error polygons. We assessed triangulation error by triangulating birds during the day, when they were roosting, and then finding the exact location. Obvious erroneous locations, large error polygons or observations where bearings failed to converge were excluded from further analysis.

To estimate the home range we used minimum convex polygon (MCP) and kernel density methods using the software Ranges 6 (v1.2208) (Kenward et al. 2003). The MCP method was initially calculated as it is a commonly estimated default standard that can be easily compared between studies, despite its inherent biases (Borger et al. 2006). Kernel density estimators provide information on the intensity of use within a home range (Worton 1995). We used fixed kernel estimators with the least squares cross validation (LSCV) to estimate the smoothing parameter (Seaman et al. 1999). 


\section{Results}

Fifteen adult rūrū ( 9 males and 6 females) were tracked intensively from September 2009 until October 2010. Five birds were tracked within the Walker Creek study area and 10 birds in the Knobs Flat area. A total of 1550 locations were recorded for the 15 adult rūrū (1048 night-time triangulations and 502 daytime locations). The average number of locations recorded for each bird was 103 (range $=31-181$ ). An incremental analysis indicated that $75 \%(15 / 20)$ of the original rūrū with transmitters had sufficient data for a robust home range analysis estimate. Home range was considered to be fully revealed if an asymptote was reached, but near asymptotes were also included if there were only small stepwise increases after a plateau had been reached. Rūrū without enough location data to reach an asymptote were eliminated from the analysis. The mean $( \pm 95 \% \mathrm{CI})$ error of our triangulations was $181 \pm 49 \mathrm{~m}$.

Foraging home ranges varied in size between individuals and for each of the home range methods (100\% MCP: 41-499 ha; 75\% kernels: 7-87 ha). Home ranges can be overestimated by $100 \%$ MCP and the $95 \%$ kernel (White \& Garrott 1990; Seaman et al. 1999; Borger et al 2006) and this, combined with the error polygons resulting from triangulation, meant that the results were less representative of the home range, whereas the $50 \%$ kernel only provided an estimate of the core home range. The $75 \%$ kernel appeared to closely resemble the areas covered by the foraging locations and excluded the major outliers so was used in the subsequent analysis (Fig. 2).

Although there was no apparent difference between male and female home ranges $\left(t_{12}=-0.84, P=0.41\right.$ or between Walker and Knobs Flat $\left(t_{13}=-0.13, P=0.9\right)$ this result may well have been confounded by site, as only male birds were tracked at Walker Creek. The mean $( \pm 95 \% \mathrm{CI})$ home range based on $75 \%$ kernel analysis was $43.5 \pm 13.4$ ha for each bird. The spread of a range is the grand mean of distances between all the locations within the kernel - the mean $( \pm 95 \% \mathrm{CI})$ for the $75 \%$ kernel was $270 \pm 42 \mathrm{~m}$. The range span is a linear estimator of home range (Table 1 ). The $75 \%$ kernel home ranges show that 11 out of 14 call count stations would be within a rūrū territory if stations were spaced at 500-m intervals (Fig. 2). The capture data showed that there were at least eight pairs of rūrū within the Knobs Flat grid (16 individuals) but we only had home range data on seven of those pairs (Fig. 2).

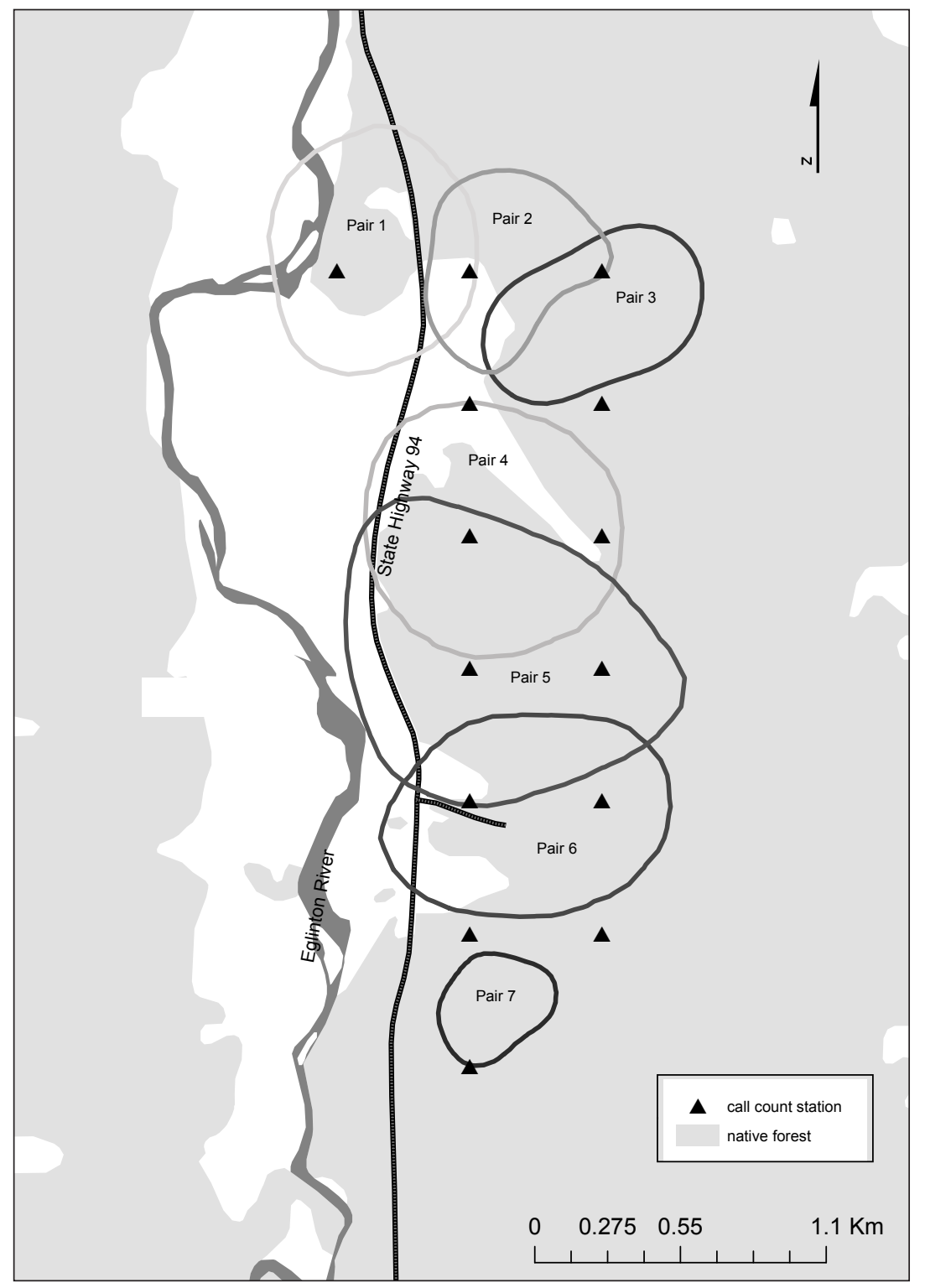

Figure 2. Examples of the locations of $75 \%$ kernel ranges at Knobs Flat for each occupied territory (range drawn for the bird in each pair with the most representative data available, as there was no significant difference between the home ranges of males and females). 
Table 1. Home range (100\% MCP, range span, 75\% kernels and range spread) for male and female rūrū at Knobs Flat and Walker Creek.

\begin{tabular}{|c|c|c|c|c|c|c|c|}
\hline Sex & Site & $100 \% \mathrm{MCP}$ & $\begin{array}{c}\text { Range span } \\
\text { at } 100 \%\end{array}$ & $75 \%$ kernel & $\begin{array}{c}\text { Range spread } \\
\text { at } 75 \%\end{array}$ & Nights (n) & Fixes (n) \\
\hline Female & Knobs Flat & 363 & 3106 & 87 & 297 & 15 & 34 \\
\hline Female & Knobs Flat & 88 & 1849 & 27 & 285 & 7 & 43 \\
\hline Female & Knobs Flat & 246 & 2628 & 23 & 179 & 17 & 97 \\
\hline Female & Knobs Flat & 60 & 1771 & 36 & 213 & 6 & 31 \\
\hline Female & Knobs Flat & 300 & 2549 & 74 & 272 & 18 & 127 \\
\hline Female & Knobs Flat & 493 & 3897 & 66 & 417 & 18 & 170 \\
\hline Male & Knobs Flat & 101 & 1555 & 7 & 306 & 16 & 69 \\
\hline Male & Knobs Flat & 381 & 2723 & 33 & 281 & 23 & 133 \\
\hline Male & Knobs Flat & 41 & 1133 & 13 & 153 & 14 & 127 \\
\hline Male & Knobs Flat & 574 & 4228 & 74 & 244 & 15 & 131 \\
\hline Male & Walker Creek & 422 & 3014 & 54 & 378 & 13 & 88 \\
\hline Male & Walker Creek & 354 & 2687 & 32 & 161 & 4 & 36 \\
\hline Male & Walker Creek & 499 & 3053 & 33 & 354 & 27 & 181 \\
\hline Male & Walker Creek & 250 & 2835 & 33 & 272 & 22 & 162 \\
\hline Male & Walker Creek & 439 & 3032 & 61 & 236 & 18 & 121 \\
\hline Average & & 307 & 2671 & 43.5 & 270 & 16 & 103 \\
\hline $95 \% C I$ & & 95 & 460 & 13 & 42 & & \\
\hline
\end{tabular}

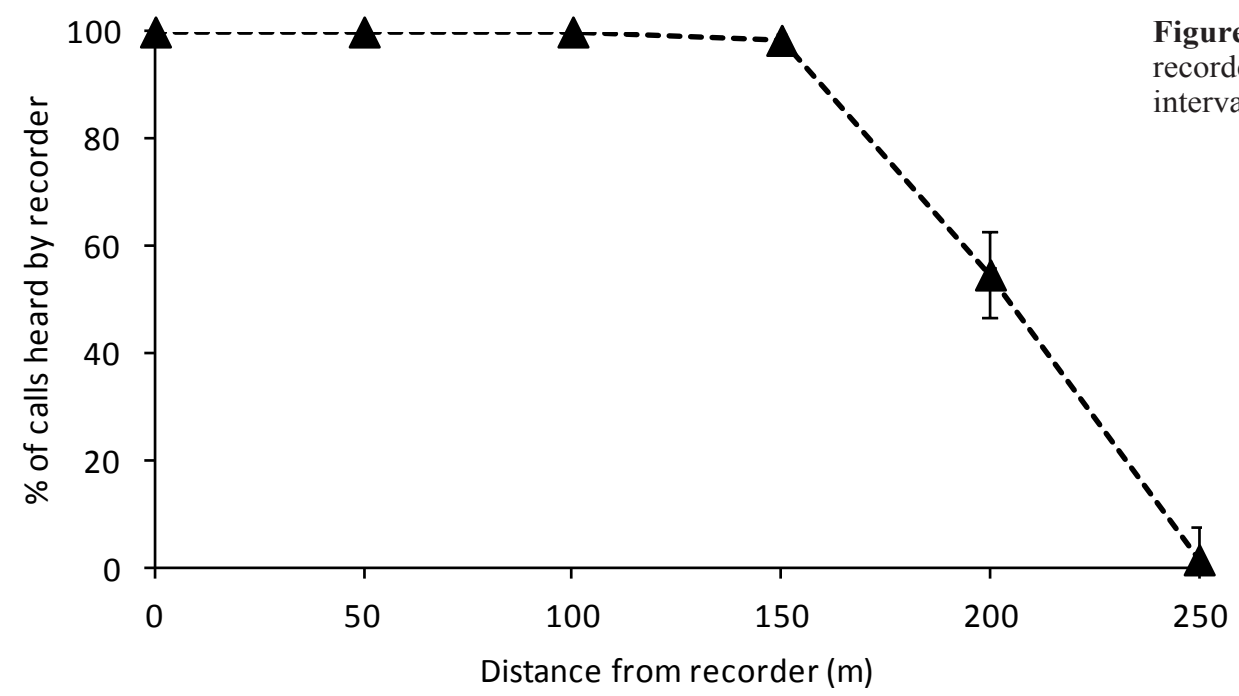

Figure 3. Distance (m) over which acoustic recorders detected rūrū calls measured at $50-\mathrm{m}$ intervals at Knobs Flat.

All calls were heard by the acoustic recording devices up to $150 \mathrm{~m}$. At a distance of $200 \mathrm{~m}, 54 \%$ of calls were heard, whereas at $250 \mathrm{~m}$, no calls were detected (Fig. 3).

\section{Discussion}

Rūrū in southern beech forest have large home ranges in comparison to other more productive forests. In previous studies of rūrū, the home range was calculated as 3.5-5.3 ha (minimum size based on daytime locations) in the Orongorongo Valley (Imboden 1975) and as 4.45-6.71 ha ( $\mathrm{MCP}=100 \%)$ on Mokoia Island (Stephenson 1998). Home range is likely to be related to food supply and habitat (Lurz et al. 2000). Southern beech forests generally have low productivity (Wardle 1984) with periodic mast events (Dilks et al. 2003) so home ranges may be relatively large to cope with low productivity years. In North Island podocarp hardwood or regenerating secondary forests, invertebrate productivity is probably higher and available food for rūrū more plentiful (Moeed \& Meads 1986). On small islands, such as Ponui Island, Denny (2009) found that rūru readily switch prey to species that are most abundant within territories. Birds therefore have to occupy a large enough territory to provide foraging in high and low food productivity years. Olsen et al. $(2002,2011)$ calculated home ranges of between 70.6 and 205.8 ha $(\mathrm{MCP}=100 \%)$ 
for southern boobook (Ninox novaeseelandiae) in urban areas of Canberra, Australia. It is possible that these birds have to range further for suitable habitat and food in a modified urban setting. Schilling et al. (2013) found that increased forest fragmentation was associated with an increase in home range and a decrease in survival.

As home ranges of rūrū are so variable, developing a generic monitoring method is problematic. Monitoring programmes should aim for independent sampling stations and the spread of call count stations should be broad enough to efficiently sample the population of interest. To improve efficiency, stratification of the sampling design is useful, particularly if there is known variation in the distribution of birds relative to habitat and other variables. Sampling independence will be related to animal distribution, home range of the species and the range of the detector, but this has to be balanced with sampling efficiency (Morrison et al. 2001.

We were fortunate that our placement of count stations at 500-m intervals covered the home range of most birds present in the study area, particularly as the average range span for the $75 \%$ kernel was $270 \mathrm{~m}$. In addition, captures of rūrū at sites less than $500 \mathrm{~m}$ apart were likely to be of the same individual, suggesting $500 \mathrm{~m}$ is a useful sampling interval within this forest type. The probability of detecting a call using the acoustic recording device declined after $150 \mathrm{~m}$ and $46 \%$ of the calls were attenuated at $200 \mathrm{~m}$, therefore the range of a detector does not adequately cover the area between two detectors. Two call count stations with this spacing are therefore unlikely to record the same bird if it calls from one location. However, if birds call from the central area between recorders, where probability of detection is low, they may not be recorded. Realistically, rūrū move through their home range and they are likely to be detected providing the sampling period is sufficient.

All stations detected rūrū calls. If it is assumed that every call count station detected a different rūrū, a maximum of 14 birds would be estimated for the study area. However, territory mapping and capture data suggested the population within the study area was at least 16 birds. This is likely to be close to the actual local population size but some non-territorial single birds may have been missed. For this reason, call count stations spaced at 500-m intervals within beech forest will provide a robust index of population size rather than an absolute estimate of population size. If population size or density is required, the design would have to be changed. The design could incorporate clusters of call count stations with a larger distance between clusters, which would allow for the limited range of the recording device but enable greater sampling of the area (Efford et al. 2009; Stevenson 2015).

In North America, the northern spotted owl (Strix occidentalis caurina) was monitored using 500-m sample unit spacing to assess territory occupancy along transects and determine trends in occupancy over time (Blackburn et al. 2001). The home range for northern spotted owls is larger compared with rūrū (100\% MCP 422-817 ha; Zabel et al. 1995). Sampling spacing may have been reduced to increase detection probability in a rare species.

Acoustic recorders show promise as a method for monitoring rūrū. Further research is needed at a range of sites to determine if spacing of stations should vary accordingly. Where the home range of rūrū is uncertain, particularly in highly fragmented landscapes or in habitats other than beech forest, an initial 500-m spacing of call counts stations is recommended to maximise sampling independence and minimise the limitations of the recording devices used. This spacing should be modified if the density and/or home range of the birds prove considerably different (larger or smaller) from this study or if the scope of the study is on a larger or smaller scale. If the distance between stations is increased, the range of the recording device will limit the sampling density and therefore the coverage of the sampling area.

If individual rūrū can be identified, reducing the distance between stations and creating a denser array of acoustic recording devices would allow the signal strength of individual calls to be measured. This would provide a framework from which spatially explicit mark-recapture data could be collected and population density estimated (Efford et al. 2009). Ramsey et al. (2015) suggested that unbiased estimates of density can be made if the device spacing is less than the radial length of a typical home range and the number of encounter occasions is high. Alternatively, population trend estimates could be computed using the occupancy rate at a number of sites that are repeatedly sampled to give a spatial distribution that accounts for detection probability (MacKenzie et al. 2002). Partial or complete automation of the identification of rūrū calls will be the key to making this a more widely used technique.

\section{Acknowledgements}

We thank Iris Broekema, Sarah Cook, Richard Earl, Brice Ebert, Lynette Hartley, Rebecca Jackson, Philip Marsh, Dan Palmer, Lyneke Onderwater, Jason Van de Wetering, Maddie Van de Wetering, Joanna Whitehead and Emma Williams for assistance in the field. We also thank Colin O'Donnell, two anonymous reviewers and Dean Anderson for helpful comments on earlier drafts that greatly improved the manuscript.

\section{References}

Allen RB, Wright EF, MacLeod CJ, Bellingham PJ, Forsyth DM, Mason NWH, Gormley AM, Marburg AE, MacKenzie DI, McKay M. 2009. Designing an inventory and monitoring programme for the Department of Conservation's Natural Heritage Management System. Lincoln, Landcare Research.

Anthony RG, Forsman ED, Franklin AB, Anderson DR, Burnham KP, White GC, Schwarz CJ et al. 2006. Status and trends in demography of Northern Spotted Owls 1985-2003. Wildlife Monographs 163: 1-48.

Blackburn IR, Alton S, Smith JNM, Godwin S, Hentze R, Lenihan CB 2001. Population assessment of the northern spotted owl in British Columbia 1992-2001. British Columbia, Canada, Ministry of Water, Land and Air Protection.

Borger L, Franconi N, De Michele G, Gantz A, Meschi F, Manica A, Lovari S, Coulson TIM 2006. Effects of sampling regime on the mean and variance of home range size estimates. Journal of Animal Ecology 75(6): 1393-1405.

Buxton RT, Jones IL 2012. Measuring nocturnal seabird activity and status using acoustic recording devices: applications for island restoration. Journal of Field Ornithology 83: 47-60.

Denny K 2009. The diet of moreporks (Ninoxnovaeseelandiae) in relation to prey availability, and their roost site characteristics and breeding success on Ponui Island, 
Hauraki Gulf, New Zealand. MSc Thesis, Massey University, New Zealand.

Dilks PJ, Elliott GP, O’Donnell CFJ 1995. Mist netting techniques - a method using telescopic aluminium poles. Ecological Management 3: 20-28.

Dilks PJ, Willans M, Pryde M, Fraser I 2003. Large scale stoat control to protect mohua (Mohoua ochrocephala) and kaka (Nestor meridionalis) in the Eglinton Valley, Fiordland, New Zealand. New Zealand Journal of Ecology 27: 1-9.

Efford MG, Dawson DK, Borchers DL 2009. Population density estimated from locations of individuals on a passive detector array. Ecology 90: 2676-2682.

Elliott GP, Wilson PR, Taylor RH, Beggs JR 2010. Declines in common, widespread native birds in a mature temperate forest. Biological Conservation 143(9): 2119-2126.

Fraser EA, Hauber ME 2008. Higher call rates of morepork, Ninox novaeseelandiae, at sites inside an area with ongoing brodifacoum poisoning compared with matched nonmanaged sites. New Zealand Journal of Zoology 35: 1-7.

Garton EO, Wisdom MJ, Leban FA, Johnson BK 2001. Experimental design for radiotelemetry studies. In Millspaugh JJ, Marzluff JM, eds Radio tracking and animal populations. New York, USA, Academic Press. Pp. 15-42.

Gaston KJ, Fuller RA2007. Biodiversity and extinction: losing the common and the widespread. Progress in Physical Geography 31: 213-225.

Gravia T, Mathevon N, Place E, Balluet P 2008. Individual acoustic monitoring of the European Eagle Owl Bubo bubo. Ibis 150: 279-287.

Greene T, Pryde MA 2012. Three population estimation methods compared for a known South Island robin population in Fiordland, New Zealand. New Zealand Journal of Ecology 36: 340-352.

Gummer H. 2012. Planning bird radio-tracking and datalogging projects. Standard Operating Procedures. Wellington, New Zealand, Department of Conservation.

Harris S, Cresswell WJ, Forde PJ, Trewhella WJ, Woollard T, Wray S 1990. Home range analysis using radio-tracking data - a review of problems and techniques particularly as applied to the study of animals. Mammal Review 20(2): 97-123.

Hausleitner D 2006. Inventory methods for owl surveys. Standards for Components of British Columbia's Biodiversity No. 42. Victoria, BC, Canada, Ecosystems Branch, Ministry of Environment for the Resources Information Standards Committee.

Hoare JM, O'Donnell CFJ, Wright EF 2010. Selection of indicator species for State of the Environment reporting: a case study from New Zealand. Pacific Conservation Biology 16: 76-82.

Imboden C 1975. A brief radio-telemetry study on rūrūs. Notornis 22: 221-230.

Karl BJ, Clout, MN 1987. An improved radio transmitter harness with a weak link to prevent snagging. Field Ornithology 58: 73-77.

Kenward RE, South AB, Walls SS 2003. Ranges 6 v1.2: For the analysis of tracking and location data. Wareham, UK, AnatrackLtd. www.anatrack.com (accessed 14 July 2015).

Lee W, McGlone M, Wright E comps 2005. Biodiversity inventory and monitoring: a review of national and international systems and a proposed framework for future biodiversity monitoring by the Department of Conservation. Landcare Research Contract Report LC0405/122. 216 p.
Lurz PWW, Garson PJ, Wauters LA 2000. Effects of temporal and spatial variations in food supply on the space and habitat use of red squirrels (Sciurus vulgaris L.) Journal of Zoology 251(2): 167-178.

Macleod CJ, Greene TC, MacKenzie DI, Allen RB 2012. Monitoring widespread and common bird species on New Zealand's conservation lands: a pilot study. New Zealand Journal of Ecology 36(3): 300-311.

MacKenzie DI, Nichols JD, Lachman GB, Droege S, Royle JA, Langtimm CA 2002. Estimating site occupancy rates when detection probabilities are less than one. Ecology 83: 2248-2255.

Moeed A, Meads MJ 1986. Seasonality of litter inhabiting invertebrates in two native-forest communities of Orongorongo Valley, New Zealand. New Zealand Journal of Zoology 13: 45-63.

Morrison ML, Block WM, Strickland MD, Kendall WL 2001. Wildlife study design. New York, Springer-Verlag. 210 p.

O'Donnell CFJ 1996. Predators and the decline of New Zealand forest birds: an introduction to the hole-nesting bird and predator programme. New Zealand Journal of Zoology 23: 213-219.

O'Donnell CFJ 2000. Influence of season, habitat, temperature, and invertebrate availability on nocturnal activity of the New Zealand long-tailed bat (Chalinolobus tuberculatus). New Zealand Journal of Zoology 27(3): 207-221.

Olsen J, Downs JA, Tucker T, Trost S 2011. Home-range size and territorial calling of Southern Boobooks (Ninox novaeseelandiae) in adjacent territories. Journal of Raptor Research 45(2): 136-142.

Olsen J, Trost S, Hayes G 2002. Vocalisations used by Southern Boobooks Ninox novaeseelandiae in and adjoining Aranda bushland, Canberra, Australia. In: Newton I, Kavanagh $\mathrm{R}$, Olsen J, Taylor I eds The ecology and conservation of owls. CSIRO, Melbourne, Australia. Pp. 305-319.

Ramsey DSL, Caley PA, Robley 2015. Estimating population density from presence-absence data using a spatially explicit model. The Journal of Wildlife Management 79 (3): 491-499.

Schilling JW, Dugger KM, Anthony RG 2013. Survival and home range size of Northern Spotted Owls in southwestern Oregon. Journal of Raptor Research 47: 1-14.

Seaman DE, Powell RA 1996. An evaluation of the accuracy of kernel density estimators for home-range analysis. Ecology 77: 2075-2085.

Seaman DE, Millspaugh JJ, Kernohan BJ, Brundige GC, Raedeke KJ, Gitzen RA 1999. Effects of sample size on kernel home-range estimates. The Journal of Wildlife Management 739-747.

Sergio F, Newton I, Marchesi L, Pedrini P 2006. Ecologically justified charisma: preservation of top predators delivers biodiversity conservation. Journal of Applied Ecology 43: 1049-1055.

Stephenson BM. 1998. The ecology and breeding biology of morepork, Ninox novaeseelandiae, and their risk from secondary poisoning, in New Zealand. Unpublished MSc thesis, Massey University, New Zealand. 219 p.

Stephenson BM, MinotEO, Olsen P 1998. Capturing, marking and radio-tracking a small owl, the southern boobook Ninox novaeseelandiae in Australasia. Corella 22(4): 104-107.

Stephenson BM, Minot EO, Armstrong DP 1999. Fate of moreporks (Ninox novaeseelandiae) during a pest control operation on Mokoia Island, Lake Rotorua, North Island, New Zealand. New Zealand Journal of Ecology 23(2): 
233-240.

Stevenson BC, Borchers DL, Altwegg R, Swift RJ, Gillespie DM, Measey GJ 2015. A general framework for animal density estimation from acoustic detections across a fixed microphone array. Methods in Ecology and Evolution 6: $38-48$.

White GC, Garrott RA 1990. Analysis of wildlife radio-tracking data. Academic Press.

Editorial board member: Dean Anderson

Received 12 August 2014; accepted 12 July 2015
Wardle J 1984. The New Zealand beeches: ecology, utilisation and management. Christchurch, New Zealand Forest Service.

Worton BJ 1995. Using Monte Carlo simulation to evaluate kernel-based home range estimators. Journal of Wildlife Management 98(4): 794-800.

Zabel CJ, McKelvey K, Ward JP 1995. Influence of primary prey on home-range size and habitat-use patterns of northern spotted owls (Strix occidentalis caurina) Canadian Journal of Zoology 73: 433-439. 